purposes, which is obliterated in the other variants, appears prominently in this second cycle of legends. It occurs also in the story of Maimonides, who is the hero of a tale found in my MS. 130 (of the sixteenth to seventeenth century). He was a favourite at the Court of the King of Spain, and became the object of envy to the other courtiers. The oldest among them then decides to bring about his destruction by the scheme of insinuating an evil smell of the breath of the king, and of Maimonides, advising the latter to cover his mouth with his hand when addressing the king. Greatly incensed at this public insult, the king orders the baker to heat his furnace and to throw into it the first man who would ask for the king's message. Maimonides, of course, is sent. On his way to the furnace Maimonides is stopped three times to take part in a religious ceremony, once by being asked. to be present at a circumcision, the second time at a wedding, and the third time at a funeral. The king's counsellor, impatient to know of the result, reaches the furnace first and is thrown in, and Maimonides is thus saved by having been stopped on his way in the performance of religious duties. The king then learns the truth, and he recognizes that a just punishment has overtaken the wicked counsellor.

It would be easy to increase the number of parallels; they are mostly mentioned in the books of Liebrecht, Koehler, and Oesterley. To this large number now the history of Candrahäsa is a most welcome and important addition, for it furnishes the missing Indian link, and eloses the chain.

M. Gaster.

\title{
The Antiquity of Vedic Culture
}

My paper on the Antiquity of Vedic Culture ${ }^{1}$ has elicited comments from various scholars ${ }^{2}$; may I be 1 JRAS, 1909, pp. 721 seqq.

2 Ibid., pp. 1095 seqq. 
allowed to make a few remarks on the strictures of Professor Oldenberg and Mr. Berriedale Keith, which concern more directly the Sanskrit scholar?

According to Professor Oldenberg the Mitannian gods, Mitra, Varuna, Indra, and the Nāsatyas, are not the Vedic gods of those names, but Iranian gods partly occurring in the Avesta, partly inferred from facts contained in the Avesta. He contends that the divine pair, Ahura-Mithra or Mithra-Ahura, of the Avesta has been correctly identified with Mitra-Varuna of the Veda; for the Vedic Varuna is indeed the great Asura ( = Iran. ahura). The Vedic Indra is concealed under Verethrajan, the god of Victory in the Avesta. And to the Vedic pair of the two Näsatyas corresponds in the Avesta the evil spirit Nāonhaithya. Therefore Professor Oldenberg says in conclusion: "I never doubted that Zarathustrianism was preceded by a more ancient Iranian religious system in which occurred a divine pair, Mitra-Varuna, a god Indra, a pair of two Aśvins or Nāsatyas."

This reasoning is open to serious objections. (1) A god Varuna is nowhere mentioned in Iranian records. We only know for certain that Mithra was associated with another great god of whose true name and functions we are totally ignorant. From the fact that both in the Veda and in the Avesta there occur a couple of gods, one of whom is Mitra, it does not follow that the second member in either couple should also be the same. For the Sun-god may be, and has been, associated with various gods, so as to form a pair with any one of them, e.g. the Moon, the Night, the Dawn, ${ }^{1}$ etc. We do not know who was the companion of that Mitra who, as Professor Sayce tells us in his note, p. 1106, is "represented by ideographs which signify 'the dawncompleter"." (2) The Iranian god of Victory, Verethrajan, corresponds to the Indian Vrtrahan; but in Indian

${ }^{1}$ Cf. Garuḍa and Aruna. 
mythology Vrtrahan is an epithet of Indra, while in the Avesta Verethrajan and Indra are two distinct mythological persons, a god and a demon. It is just as likely that the Indians should have fused two gods into one as that the Iranians should have split one into two. And besides the inscription names this god "Indra" and not Vrtrahan. (3) The Avesta knows but one Nāonhaithya, a demon, not a divine pair of Nāsatyas, thus ignoring the most characteristic trait of the Aśvins, their forming a couple. Nāsatya is an epithet of the Aśvins, the signification of which is unknown. It may, for all we know, have been also the name of an Iranian god wholly unconnected with the Indian Aśvins. The inscription does not mention one Nāsatya, but two; for the plural ilani most probably stands for the dual which is wanting in Babylonian. (4) The gods mentioned in the inscription are identical in form with Vedic gods; there is not a trace of anything peculiarly Iranian. ${ }^{1}$ This fact goes far to prove that the religion of the tribe who imported their gods into Mesopotamia was essentially the same as Vedic religion as far at least as concerns mythology. For the gods invoked in those treaties were, of course, the principal gods of that tribe.

Now the facts discussed under Nos. 1-3 prove that Iranian mythology, as revealed in the Avesta, bears some resemblance to Vedic mythology (as far as concerns the gods under consideration), but that, on the other hand, the difference is also well marked. And this is

1 Professor Oldenberg says, p. 1098, note 1: "By deriving these gods from Iran rather than from India we may possibly account for the absence of Agni. It seems probable that the prominence of Agni in the Veda is of Indian, not of Indo-Iranian, growth." In my opinion the prominence of Agni in the Veda is due to the fact that Agni (like Soma) was a god of the priests (in later times he is identified with the Brahmans), while Indra was the god of warriors or Kṣattriyas. Therefore the absence of Agni from the Mitannian inscription is easily accounted for by the fact that the Mitannian kings or their predecessors were warriors and not priests. 
just what might be expected in two distinct peoples derived from a common stock; we know of no instance where two such peoples, each of which, however, developed an individual language and nationality, have preserved the same gods and attributed to them the same relative importance as in the prehistoric times when the two peoples had not yet separated. For the causes which bring about linguistic and ethnical differentiation, still more powerfully affect the religious beliefs of the people and their selection of gods. ${ }^{1}$

These considerations make it highly improbable that the gods invoked in the Mitannian inscriptions should be Iranian, or, more accurately, proto-Iranian ${ }^{2}$ gods. Now the obvious reason for assuming them to be Iranian is the apparently Iranian form of the names of the Mitannian kings. But according to Professor Sayce ${ }^{3}$ it is very unlikely that the names of the Mitannian kings are either Indo-European or Iranian; and this eminent scholar shows that the seeming Iranian affinities of these names may just as well be explained from Mitannian and Hittite idioms. If he is right, there is no reason which could induce us to interpret as Iranian, gods who, on the face of it, are Vedic gods.

1 Popular gods usually vary even from tribe to tribe within the same people unless a uniform mythology is brought about by some powerful factor; as the Greek Pantheon was fixed by the Homeric poems, so the Vedic Pantheon by the Vedic Rșis. If, therefore, contrary to my opinion, it could be proved that the pre-Zarathustrian religious system of the Iranians contained the principal gods of the Veda, then indeed we should have to assume that those Iranians had, at some time, been so wholly under the influence of Vedic culture as to adopt even the Vedic gods.

2 Professor Oldenberg corrects me in ascribing to Professor Meyer the opinion that those gods were Arian instead of proto-Iranian. If I must plead guilty, I may say in my excuse that the title of his paper: "The first appearance in history of the Arians," and some passages, e.g. the one translated by Oldenberg on p. 1096, have misled not only me but also ther readers.

3 JRAS, 1909, p. 1107. 
Professor Oldenberg thinks that even if these gods should, after all, turn out to be Vedic gods, their occurrence on Mitannian inscriptions of about 1400 B.c. will make no alteration in the current opinions on the age of the Veda; and he objects to my declaration that the excavations at Boghazkiöi "give an entirely new aspect to the whole question of the antiquity of Indian civilization". But their importance in this regard will be evident to everyone who considers that till recently the oldest authentic date in Indian history was the epoch of Buddha's death, and that now the oldest certain date is pushed back for well-nigh a thousand years. The testimony which the Mitannian inscriptions bear to the existence of Vedic religion about 1400 B.c. will henceforth be the keystone of all speculations on the antiquity of Indian civilization.

I had contended that everybody would accept my interpretation of the dates brought forward by Mr. Tilak and myself in order to prove the high antiquity of Vedic civilization, if the latter could be proved by independent evidence. Mr. Berriedale Keith, however, is of opinion that the objections to my chronological arguments would remain in undiminished force, even if the Vedic culture should date from the early epoch I claim for it. And in order to make his assertion good he restates the reasons of my opponents in a condensed form. May I, therefore, be allowed to give also my version of the story?

(1) The Vedic year began with full moon in UttaraPhalguni ( $\beta$ Leonis); our opinions are at variance about the epoch denoted by this beginning of the year. I believe that at the time when the oldest Vedic calendar was fixed, the full moon in Uttara-Phalguni occurred at the winter solstice; but according to Oldenberg it marked the beginning of the hot season. He places the period of the oldest Brāhmanas during which the calendar may have been fixed at about 800 B.C. At that time the full moon 
in question occurred, as an easy calculation shows, within a fortnight on either side of the 3rd February. Now if we place the first construction of the Vedic calendar 800 years earlier, as the Boghazkiöi inscriptions entitle us to do, the limits of Phālguna full moon are shifted forward to the 10th January and the 7th February. Therefore, from the assumptions of Oldenberg, Thibaut, and others, it would follow that the Indians, when first framing their calendar, marked the beginning of the hot season by the full moon occurring between the 10th January and the 7th February. As such a proposition is quite unacceptable in my opinion, I think it preferable to interpret the said beginning of the year as marked by the winter solstice of a very early period. For the winter solstice was also the beginning of the lustrum and the first year of it in the adjusted calendar of the Jyotisam which at that time coincided with new moon in Māgha (about 1100 B.C.).

I proceed to discuss two more dates which, in my opinion, bear testimony to the existence of a polar star (dhruva) and the position of the Pleiades near the vernal equinox in the early Vedic age. My opponents deny that the alleged evidence contains a positive base for chronological inference.

(2) The dhruva (lit. the immovable one) was during the marriage ceremony pointed out by the husband to his bride as a symbol of immobility. Mr. Berriedale Keith ${ }^{1}$ emphasizes the fact that the dhruva "among Vedic texts appears only in the marriage ritual of the Grihya Sütras and in the late ( $\mathrm{I}$ should say apocryphal) Upanișadic literature". But as the pointing out of the polar star as a part of the marriage ceremony is enjoined in all the principal Gṛhy Sütras, it was obviously a usage prevailing all over India and, therefore not one of recent origin. ${ }^{2}$

1 1.c., p. 1101.

2 It is misleading when Keith says (ibid.) that the "dhruva is admittedly an intruder in the Vedic marriage ritual". Professor Winternitz, speaking of another detail of the marriage ritual, which is of 
Now I contend that the dhruva was the polar star of the period in which the popular custom of showing it to the bride came into existence; for it is difficult to imagine that the Indians should have wantonly named a star immovable whose motion could not have escaped observation. It was, of course, natural for this star to retain the name once given it for an indefinite length of time, even after it had ceased to appear immovable. ${ }^{1}$ The opponents of my theory seem to suppose that the ancient Indians invented, as it were, a polar star, and then fixed on a star in the vicinity of the Pole to call it dhruva. However, the absence of anything like astronomical theories before the Puranic period makes this assumption unaceeptable, in my opinion. I am convinced that it was not the priest who invented a polar star, but that the common people, villagers and the like, had discovered it. On this assumption I identified the dhruva with a Draconis, which star was, in 2780 B.c., only six minutes distant from the Pole, and continued for about three or four hundred years before and after that time in such vicinity to the Pole that it may have been regarded as a true polar star. Only two more stars of sufficient magnitude approached the Pole: $\kappa$ Draconis and $\beta$ Ursø Minoris, the minimum

unmistakably Indo-Germanic origin, points out that it is mentioned in two Grihya Sūtras only, and he adds the remark that this fact should caution us against drawing an inference as to the absence of a popular custom from the absence of a testimony for it in the oldest literature. Das altindische Hochzeitsrituell, in Denkschriften der Kaiserl. Akademie der Wissenschaften in Wien, vol. xl, p. 177.

1 The phrase dhruvasya pracalanam in Maitrĩ Upanișad, i, 4, has been regarded as evidence that the motion of the polar star had become known at last. But this is a mistake. The shaking of Dhruva is mentioned among other portents which were apparently supposed to occur at the end of a Kalpa: soṣanam mahārnavānām, sikharinăm prapatanam, vraścanam vātarajjünäm. We are here already in presence of Puranic cosmology ; note the cords of winds by which the stars are fastened to the Dhruva, see Viṣnu Purāṇa, ii, 12, 24. For the Purānas Dhruva (Auttanapada) seems to be the Pole, as guardian of the celestial bodies; and the star near him is his mother Sunīti or Sūnṛta, see Viṣnu Purăna, i, 12, 95. 
polar distance of the former being $4^{\circ} 44^{\prime}$ in 1290 B.C., and of the latter $6^{\circ} 28^{\prime}$ in 1060 B.c. But neither could have been named "immovable", since the daily changes in the position of the one amounted to about 10 degrees, and of the other to about 13 degrees, and they increased as time drew on. These are quantities not to be overlooked by men familiar with the starred heaven, as those Indians must have been who told the day of the month and the time of the night by observing the asterisms. I have treated elsewhere ${ }^{1}$ at some length the astronomical side of the question. My observations appeal to those who by a practical acquaintance with astronomy can form an adequate idea of their significance, and realize that 10 degrees make a very perceptible difference of position. Mr. Berriedale Keith, who says that my "observations on this point do not seem convincing", will give me leave to doubt his competence as judge in astronomical matters, since on p. 1102 of his paper he gives vent to the opinion that a star of 3.3 magnitude is brighter than one of "only" $2 \cdot 0$ magnitude.

(3) The last argument from the Krttikâs, or Pleiades, assumes that they opened the series of Naksatras as standing, at that time, near the vernal equinox. With this interpretation of that well-known fact I combined two testimonies from the Brāhmanas: $(a)$ in the Taittiriya Brāhmana I, 5, 2, 6 seqq. the Nakșatras are divided into devanakṣatras, Krrttikās down to Viśākhe, and yamanakşatras, Anurādhās down to Bharaṇi, the former being apparently regarded as the Northern, and the latter as the Southern, Naksatras; (b) in the Satapathabrähmana II, 1, 2, 3, it is said that the Krttikās do not deviate (cyavante) from the East, ${ }^{2}$ while the other Nakșatras do; the meaning of this observation is that

${ }^{1}$ See Festgruss an Rud. von Roth, 1893, pp. 72 seqq. ; ZDMG., wol. xlix, p. 228 ; vol. 1, p. 70.

2 Sāyana's commentary runs thus: dakșinata utiarato v'ā vikșepavasãn na calanti, kuṃtu niyamena śuddhaprācyäm evo dyanti. 
the Krttikās rise due east, as was the case when they stood near the vernal equinox. To my observations on this point, ${ }^{1}$ which I do not think invalidated by the remarks of Oldenberg and Thibaut, I may add that the Hindus in later times did not doubt the proposed significance of the Krrttikass' place at the head of the Nakșatras. For when at last they had become aware of the precession of the equinoxes, some astronomers (Sūrya Siddhanta) assumed a libratory movement of the vernal equinox, the limits of which were 27 degrees in either direction from the beginning of Aśvini (near $\zeta$ Piscium), thus including in the libration the Krttikās. Mr. Keith considers the argument from the Krrttikās also quite unconvincing, and he lays stress on "the fact that in no other regard does the vernal equinox appear as important in Vedic literature". But does the fact that Vedic liturgy took no cognizance of the vernal equinox preclude its being known? It is further said: "We do not know the origin of the Nakșatras, and until we do, it is hardly likely that the origin of the place of Krttikäs will be found." If the Krttikās rose due east in the Vedic period-viz. if their position then was near the vernal equinox-it matters little what was the origin of the Nakṣatras.

Whatever will be the value assigned to my chronological argument by the progress of research, at the present I do not think my opponents entitled to treat it as definitely refuted.

HermanN Jacobi.

\section{The Antiquity of Vedic Culture}

The importance of the question of the interpretation of the chronological data of the Vedic literature renders desirable a brief reply to Professor Jacobi's last note on the subject.

I See ZDMG., vol. xlix, pp. 220 seqq.; vol. 1, p. 72. 